Article

\title{
Analysis of the Accommodation Density in Coastal Tourism Areas of Insular Destinations from the Perspective of Overtourism
}

\author{
Moisés Simancas Cruz ${ }^{1, *}$ and María Pilar Peñarrubia Zaragoza ${ }^{2}$ \\ 1 Department of Geography and History, University of La Laguna, 38200 San Cristóbal de La Laguna, Spain \\ 2 Department of Geography, University of Valencia, 46010 Valencia, Spain; M.Pilar.Penarrubia@uv.es \\ * Correspondence: msimancas@ull.es
}

Received: 13 March 2019; Accepted: 20 May 2019; Published: 29 May 2019

check for updates

\begin{abstract}
Accommodation saturation is transcendental in island destinations; especially when we include it in the sustainability paradigm. A coastal tourism area is considered saturated when tourists feel the area is overbuilt. This can lead to unpleasant experiences that decrease tourist satisfaction-diminishing the competitiveness of the destination. This issue is especially relevant in insular areas. However, estimating optimal levels of accommodation density is complex, with many conceptual, methodological and operational controversies. Moreover, there is a lack of measurement data and assessment standards at the micro-local scale. The main objective of this paper is to analyse tourist accommodation density because it is commonly used to measure the level of saturation in urban coastal tourism areas. The intention is to identify from the perspective of overtourism, the weaknesses of using tourist accommodation density as a parameter to assess the urban saturation of coastal tourism areas located in the destination, the Canary Islands, Spain. A systematic method of observation and interpretation is employed to examine the use of density indicators and assess their efficiency. The main conclusion is to determine the optimal accommodation density. In order to achieve this, we must consider more than just the pressure and condition indicators; we also have to examine other related responses to the behaviour of the demand and, more specifically, the level of satisfaction of the tourists. The objective of this work is to evaluate the weaknesses of using tourist bed places as an indicator of the level of saturation in a coastal tourism area.
\end{abstract}

Keywords: Coastal tourism areas; density; saturation; overtourism; tourism accommodation

\section{Introduction}

"Overcrowding", "saturation" or "congestion" of a tourist destination, area, space or even a more localized place, are pejorative descriptions that refer to the negative influence of tourism on the perceived quality of life of local residents and/or the experiences of visitors [1]. In line with the geographic perspective of the definition of tourism destination provided by the World Tourism Organization [2], one of the essential characteristics of coastal urban tourism spaces is the spatial concentration of tourist accommodations and of equipment, infrastructure and leisure and service facilities, where tourists spend the night and carry out part or all of the activities they engage in during their stay. This territorial dimension of overcrowding gives rise to the concept of "accommodation saturation", "accommodation overtourism" or "accommodation overcrowding".

Using the World Tourism Organization's doctrinal definition of carrying capacity [3] and, above all, the largely accepted definition put forth by Mathieson and Wall [4], who see it as "the maximum number of people who can use a recreational environment and without an unacceptable decline in the quality of the recreational experience", accommodation saturation occurs when certain carrying 
capacities of an urban-tourism space are deemed to be overloaded by tourist accommodations and accommodation places. In this way, it is related to a feeling of "overcrowding".

From this perspective, qualifying a tourism area as "saturated" verifies the existence of a negative impact, understood as a change seen as undesirable by tourists; thus, it increases the difference between the perceived value and the expected value of the model developed by Kotler, Bowen y Makens [5]. This is because accommodation saturation in a tourism area has a decisive influence on how the tourist perceives its quality $[6,7]$ or its perceptual quality $[8,9]$. Thus, using the definition of the psychological carrying capacity of tourists [9], a coastal tourism area could be considered saturated from the point of view of its tourist accommodations, when it reaches a minimum level of tourist satisfaction, so that the tourist's interest (tolerance) is unacceptably altered.

The effects of crowding on evaluations of the experience, such as satisfaction, are similarly complex. The relationships between crowding perceptions and visitor satisfaction are not as yet clear [10]. Some authors report that perceptions of crowding can affect visitor satisfaction [11,12], especially in the case of sun and sand destinations [13]. Other studies report that although an increasing perception of crowding can have a negative effect on the quality of the tourist experience, it does not necessarily diminish visitors' satisfaction [10].

In this context, measuring accommodation saturation in coastal urban-tourism spaces requires using a set of indicators; one of these is urban density. This is a legal technique for setting minimum physical parameters as quantifiable (and, therefore, objective) limits, as well as desirable characteristics or levels of facilities. In our case, the accommodation place becomes the true measure of tourism, as it is the basic reference for the surface area of green spaces, pools and sports facilities, etc., of a tourist accommodation. At the same time it defines a specific format of urbanization, even up to defining territorial models of tourism development $[14,15]$. This perspective approximates the issue of tourist density to that of the "overtourism". This is because the tourism density is considered the main causes of overtourism and the most relevant indicators for your measurement [16].

However, determining the level of accommodation density in coastal tourism areas is complex and with numerous conceptual, methodological and operational controversies. This issue is even more relevant, if possible, for island destinations, because insularity provides certain areas specific, unique and permanent characteristics that differentiate them from continental destinations.

This paper is inserted in this context. It examines the weaknesses of using accommodation density to measure the level of urban saturation of a coastal tourism area, while also providing some conceptual and procedural questions to aid in its determination. To do so, a systematic method of observation, measurement and interpretation is applied which allows us to not only examine the use such density indicators, but also to evaluate their efficiency based on the evidence. In order to provide an applied (rather than speculative) dimension to the general statements presented, we base our work on the evidence found in the Canary Islands (Spain) destination. We believe that it is an innovative term, in that it not usually considered in the literature on overcrowding, overtourism or tourismphobia. The hypotheses for verification are following:

- Tourism accommodation density is the most relevant parameter to measure the level of urban overcrowding in a coastal tourism area. This indicator is significant because it determines when urban overcrowding in such areas reaches a point that is undesirable for tourists, when certain carrying capacities of the area are considered to be exceeded, because they are saturated with tourist accommodation establishments and bed places. Similarly, tourist accommodation density is used as an argument when overcrowding reaches levels that cause certain tourist destinations to enter the decline stage, following the normal life cycles; remember that urban and tourism planning instruments have introduced density control indexes in order to alleviate overtourism situations. That is why we still believe that it could be used to characterize coastal tourism areas. However, using this indicator leads to some complications.

- Tourism density is one of the main causes of overtourism. A coastal tourism area can be considered saturated by tourist accommodations when tourist satisfaction reaches a minimum level. In this 
way, tourist satisfaction is a perception factor that can be used to estimate when a coastal tourism area is oversaturated with tourist accommodations when that minimum level is reached, to the point of being unacceptable However, there is no direct correlation between accommodation density and level of satisfaction, at least in coastal tourism areas in the Canaries, as the high densities zones still produce high levels of satisfaction among tourists.

\section{Tourist Accommodation Density and Overtourism}

While the overtourism phenomenon is a relatively new term -in the public and academic debate on the negative consequences of tourism that was largely non-existent prior to 2017; it has been used in political debate, media reporting [17], arguments made by business lobbies and traditional businesspeople in the sector, the anti-tourism movements or 'resistant identities' [18] and has even entered the everyday language of the general public.

However, the phenomenon itself is not a new one, as problematic forms of tourism crowding. It emerged in public discourse and describes phenomena that were discussed in the scholarly literature long before the term became popular, with the debate on harmful effects of tourism going back to the 1960s [19]. Given that the studies exploring the pressure of tourism on local communities emerged in the 1970s, alongside discussions on the risks of destination saturation $[3,20,21]$, overtourism is not a new problem [22], although, as mentioned, the term itself is relatively new. Therefore, even though some consider the term to be "fuzzy", in that it is ill-defined, lacks clarity, and is highly difficult to operationalize [19], the contributions and focuses derived from the proliferation of research and grey literature publications over the past three years related to overtourism $[1,10,11,16,19,22-31]$, represent a paradigm shift [32] in approaches to tourism sustainability, carrying capacity, the impact of tourism or destination evolution theories; in this sense, the term overtourism is used to allude to traditional concepts, to transcend its eminently theoretical aspect, and, above all, to provide a management approach that has been praised as innovative, sustainable, and a key to success [33]. The same occurs with tourist saturation in coastal tourism areas; it opens up new lines of research, such as the one put forth in this work. Nevertheless, we are aware that the marketability and popularity of the phenomenon overtourism appears to be at least partially accountable for its entry into academia, rather than its explanatory value [34].

In this paper, we have employed it as a theoretical framework for our discussion on the saturation of tourist accommodations in coastal tourism areas, in order to place the issue within a corpus of knowledge. Overtourism is a new buzzword for existing concepts of tourism congestion management [1] and the application of the classic concept of tourism carrying capacity $[6,7,20,35-40]$, theoretical models of the evolution of a tourism space [41-43] and urban overcrowding [44]. Overtourism also describes how at certain times and locations the impact of tourism exceeds physical, ecological, social, economic, psychological, and/or political capacity thresholds [16]. In this sense, it provides a suitable framework, based on current conceptual references, on which to base our hypotheses, to define the problem of accommodation saturation in coastal tourism areas and interpret the results of our study. As such, in some ways it may be seen as a vehicle for renovating existing ideas $[45,46]$. This is the context of our paper.

In coherence with the definitions of overtourism provided by the Responsible Tourism Partnership and the UNWTO [1], in which the relevance of the term is related to the fact that it emphasizes that the quality of life in the area or the quality of the experience has deteriorated unacceptably". In this way saturation and carrying capacity have a strict relation with the overtourism. Our study focuses on the latter aspect by analysing the repercussions that an excessive number of accommodations in tourism destinations can have on the tourist experience. More specifically, it analyses how tourists perceive accommodation saturation from the perspective of tourism supply, instead of the commonly used approach, which focuses on the demand.

Finally, this paper extends the perspective of overtourism to coastal tourism areas. The majority of work in this area focuses on excessive or mass tourism in non-tourism areas or in areas that 
were not specifically created for tourism, with no planning and, above all, no management [22]. This lack of direction gives rise to conflicts between the right for tourists to travel and the rights of residents [22,23,26,47-49], especially residents who are not involved in tourism activity and only perceive the negative effects of tourist overcrowding. These studies have focused almost entirely on the consequences of the touristification to the cities [32,34,48-54] and on outdoor recreation $[1,12,50]$. This is also true of studies that have examined the conflicts and attitudes related to tourismphobia, which includes Coping with success: Managing overcrowding in tourism destinations [23], which has been analysed in academic circles $[20,27,53]$. There has also been increased academic analysis of the exhaustion of the dominant global tourism model based on growth, which has even sparked discussion of tourist degrowth or deturistization. However, while overcrowding is a well-known phenomenon primarily associated with negative experiences emerging from the presence of too many tourists at certain places and times, overtourism is a much broader and more complex phenomenon. That is why we feel that applying overtourism to our analysis of accommodation saturation in coastal tourism areas is a conceptual and methodological opportunity.

\section{Using the Density of Tourism Accommodations Spaces to Determine the Level of Saturation in the Canary Islands}

\subsection{The Tourism Accommodation Saturation in Insular Destinations}

Accommodation saturation is transcendental in island destinations, especially when we include it in the sustainability paradigm [55]. The impact of insularity on territorial planning for tourism is manifested in the consideration of the islands as closed, fragile, discontinuous and limited systems [56]. Not only does this complicate the management of key environmental factors, but also has an impact on its carrying capacity and, therefore, the multiple dimensions of sustainability (environmental, economic, social and even institutional). At the same the territorial characteristics of islands make considering accommodation saturation different than in continental areas. For example, the combination of a high annual number of tourists per 100 inhabitants (Tourism Penetration Rate) and the annual number of tourists per $\mathrm{km}^{2}$ (Tourism Density Rate) puts a destination at a high risk of overtourism in islands and coastal destinations [16].

This concern for tourism overcrowding is especially relevant in the insular spaces of the Canaries. It is one of the main European destinations of mass tourism; according to the Canary Islands Statistics Institute (ISTAC), the islands received 15,975,510 tourists in 2017 and are ranked first in Europe for overnight stays of non-residents in tourist accommodations. However, because the demand is not seasonal, there are no concentrations of tourists at certain times of year.

This is not the case with the territorial aspect of accommodation saturation. Of the seven islands in the archipelago, the majority of the 415,287 regulated accommodations places in the Canaries in 2017 are concentrated on the four islands that have a consolidated tourism sector (Tenerife, Gran Canaria, Fuerteventura and Lanzarote). At the regional scale there is an average of 61 accommodations places per square kilometre; Gran Canaria is the island with the greatest density, with 91 accommodation places per $\mathrm{km}^{2}$, followed by Tenerife (58), Lanzarote (55) and Fuerteventura (20). Meanwhile on the less touristic islands, the ratio is 15, 11 and 4 in La Gomera, La Palma and El Hierro, respectively. If we consider a desirable density to be around 50-60 accommodation places per $\mathrm{km}^{2}$, which would be approximately two hectares per accommodation space, the islands with consolidated tourism have all surpassed "sensible" levels (optimal threshold) of usage of the territorial system for tourism, with the exception of Fuerteventura. This is why the Exceltur report entitled "Monitoring the relative tourism competitiveness of Spanish autonomous communities" [57] placed the Canaries in the 11th position (of 15) in the level of overcrowding of municipal territory that has already been urbanized, although its human pressure per $\mathrm{km}^{2}$ was slightly below the average for all communities with 15,296 inhabitants and tourists per $\mathrm{km}^{2}$. Another aspect to consider is the occupancy of municipal territory, which measures the percentage of occupied land in the 10 non-urban municipalities with the greatest number of regulated accommodations spaces; in other words, it measures the total area of plots that have 
been built upon in each tourism municipality in relation to the total area of the municipality. Here the Canaries destination was above the average, occupying the 7th position (of 15).

High levels of occupancy make tourists feel uncomfortable (psychological carrying capacity) because the installations, facilities, equipment, and infrastructure become overcrowded (physical carrying capacity) and the environmental quality of the area is degraded (ecological carrying capacity). A feeling arises among visitors that there are too many tourists, accommodations spaces and/or constructed space (perceptual carrying capacity). Finally, the residents (hosts) begin to manifest their rejection of the tourists (guests) (social carrying capacity). Therefore, the perception that a tourism area suffers from accommodation saturation can lead tourists feel less comfortable and enjoy themselves less, causing them to lose interest in the destination and not return, or even to advise other potential tourists not to visit. In this way it influences the image of the tourism area and the destination's attraction [39]. This could generate a negative perception of the destination, with the consequent impact on the main indicators of tourism (number of overnights, average stay, etc.) and business profitability (occupancy rates, average daily revenue per available and occupied room, etc.). In other words, it can cause the destination to become less competitive (economic carrying capacity). Therefore, excessive accommodation saturation puts a tourism area in a decisive, critical and highly uncertain situation, which can even be accompanied by symptoms of degradation/exhaustion [7]. If no action is taken, this can lead to the final stages of degeneration, with the consequent decline and even, if it is prolonged, decay of the destination. Thus, it is another of the factors that influence the decline in tourism flows, in that tourists and tour operators choose alternative [20] or emerging destinations that are less crowded, located in nearby areas, other municipalities or even other countries.

In this context, it is not hard to understand why accommodation saturation is taken into consideration in territorial planning for tourism in the Canaries. The first known reference is found in Decree 108/1999, in which the regional tourism administration declared the island of Lanzarote a "saturated area". Later, a study entitled, "Evolution of insular indicators", carried out within the LIFE Lanzarote 2001-2004 project, suggested that this island's carrying capacity had been surpassed. Article 58 of Law 7/1995, April 6, Regulating Tourism in the Canaries, indicates the need to establish projections regarding the "maximum capacity" and "limits" of tourist accommodations. The Canary Islands Tourism White Book (1997) revealed the decline of the global model of tourism and the risk of entering into a crisis of viability and profitability. The Parliament of the Canaries, in a session held on 22 and 23 March, 2000, debated a legislative proposal made by the Canarian Socialist Party to study the carrying capacity of each island in order to determine the level of tourism they could handle. Ultimately, the "Canary Islands tourism moratorium" (2001-present) was justified by the need to avoid surpassing the tourism carrying capacity of the islands.

\subsection{The Accommodation Saturation in Coastal Tourism Areas}

Given that the Canary Islands specializes in coastal vacation accommodations, a large part of the tourism establishments are located on only $1.76 \%$ of the total area of the region [58]. The territorial concentration of urban-tourism explains why the coastal tourist areas in the archipelago have densities similar to central European cities.

Despite this, $60 \%$ of these areas have densities lower than the regional average (121,461.10 visitors housed per $\mathrm{km}^{2}$ ). This number was obtained from the following sequential procedure proposed by Simancas et al. [58] (Figure 1): identification and delimitation of each plot occupied by a tourism establishment $\rightarrow$ association of alphanumeric information (typology, category, age, etc.) $\rightarrow$ application of condition indicators related to the state of accommodation saturation (Table 1) $\rightarrow$ cartographic representation of the indicators through $\mathrm{km}^{2}$ grids $\rightarrow$ evaluation of each indicator according to its deviation from the mean in the territorial area of reference; values above the mean can be understood as far from any degree of accommodation saturation (Table 1). Considering that accommodation density at the regional scale is 35.66 accommodation spaces per hectare and 14.08 establishments per $\mathrm{km}^{2}, 44 \%$ of tourism areas have above-average densities, concentrated in the oldest parts of these 
areas. Moreover, available land, understood as land that has not yet containing construction, excepting beach areas, predominate over other usages [59]. Public spaces represent the second greatest form of occupancy $(14.5 \%)$, followed by land occupied by complementary equipment. Finally, there is a high average level of virgin spaces on the coasts of tourism areas ( $86 \%$ ); in this sense, $26 \%$ of tourism areas have a higher level than the regional average.

\begin{tabular}{cc}
\hline Condition indicator (2017) & Playa del Inglés \\
\hline Area $\left(\mathrm{km}^{2}\right)$ & 3.82 \\
\hline $\begin{array}{c}\text { Number of accommodation } \\
\text { spaces }\end{array}$ & 59,764 \\
\hline $\begin{array}{c}\text { Number of tourist } \\
\text { establishments }\end{array}$ & 281 \\
\hline Number of travellers entered & $1,676,729$ \\
\hline Number of overnights & $14,183,346$ \\
\hline
\end{tabular}
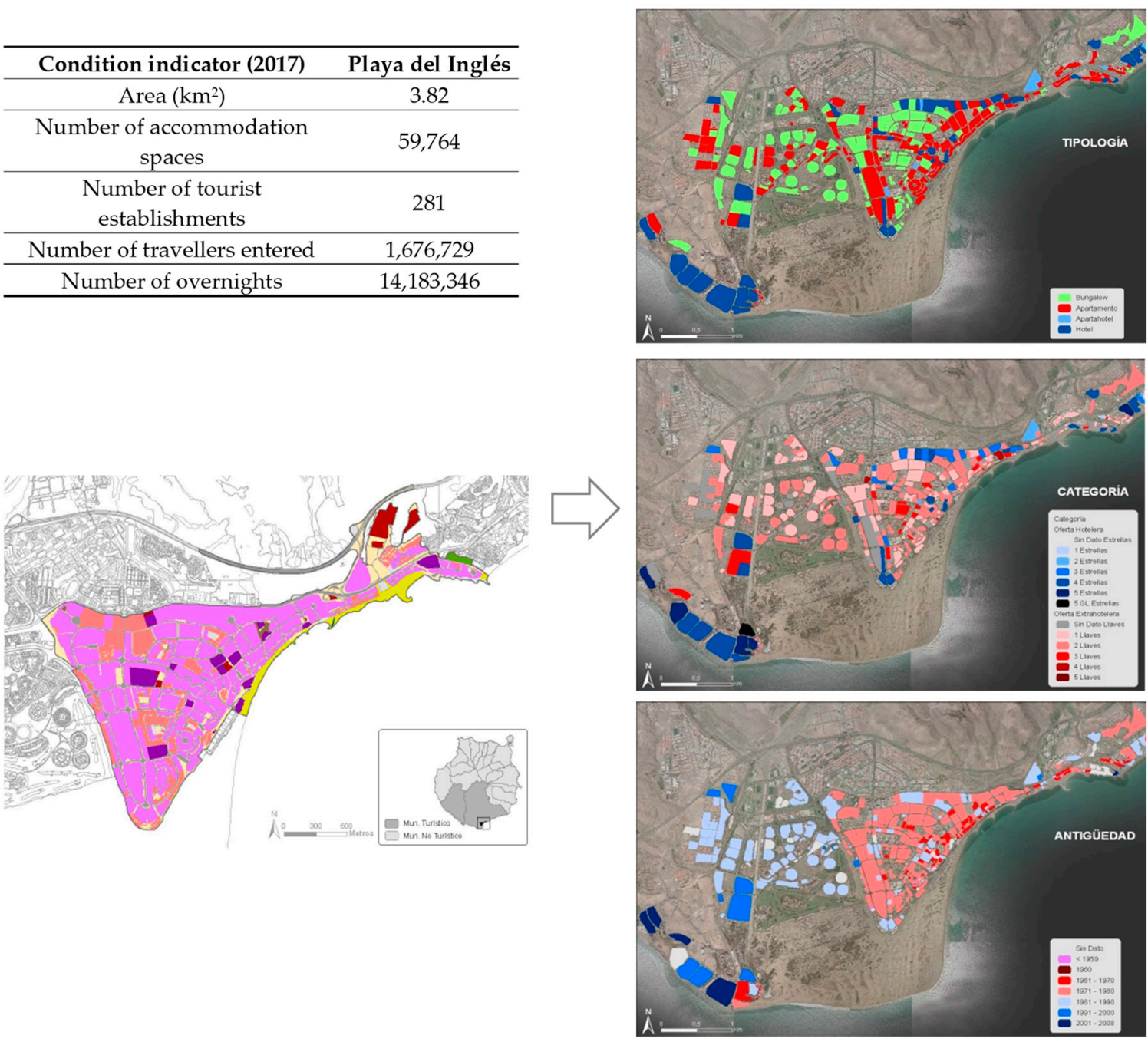

(a)

Figure 1. Cont. 
Number of establishments per $\mathrm{km}^{2}$
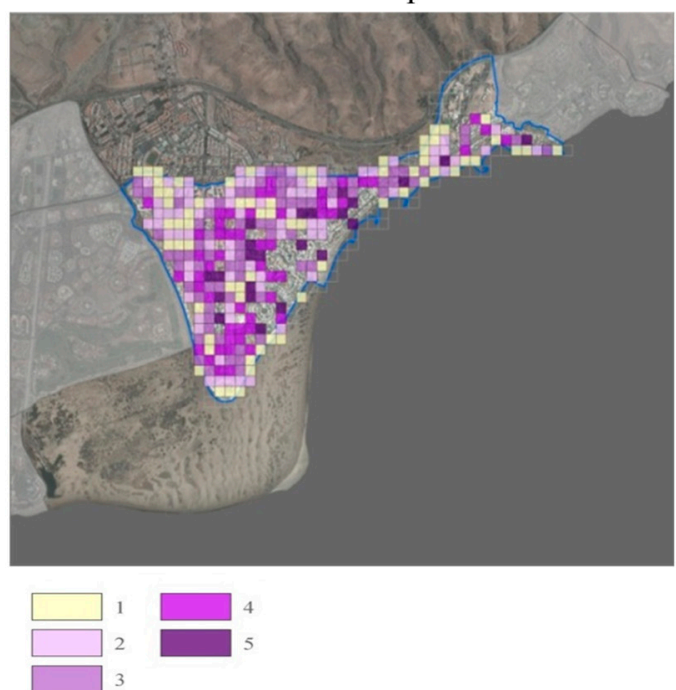

Surface area of establishments per $\mathrm{km}^{2}$

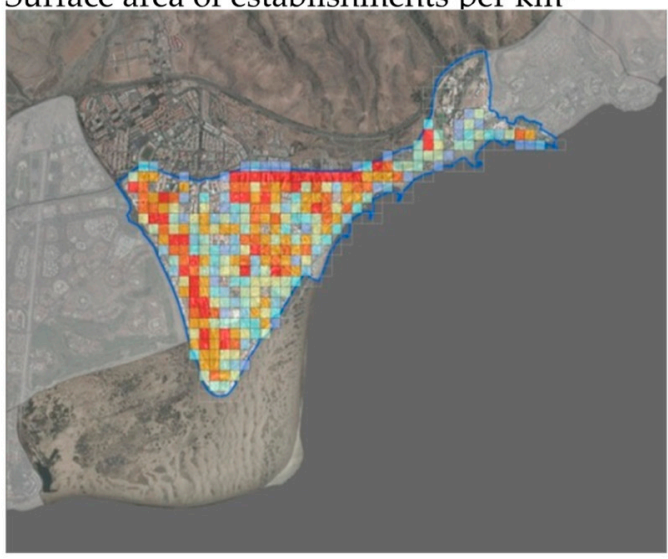

Densidad:
[Km2 Oferta Alojativa] $0,000-0,001$

$0,001-0,002$
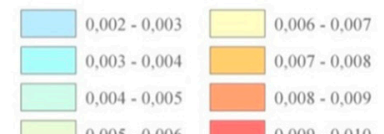

Number of accommodation spaces

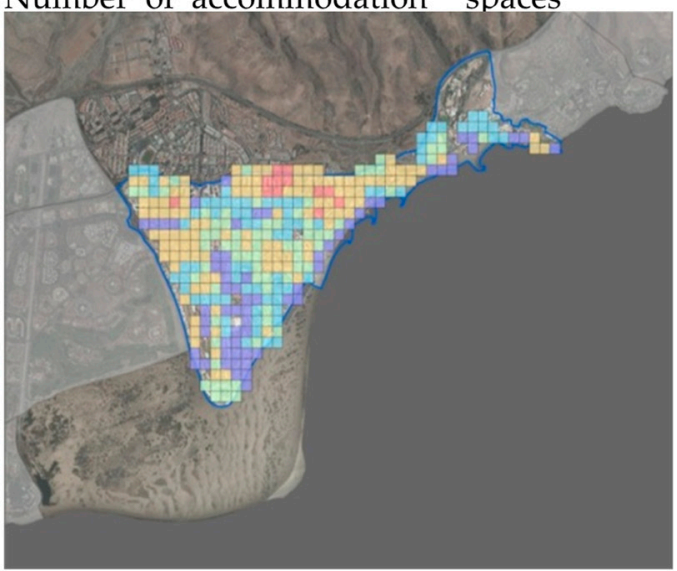

Densidad de Plazas [Plazas / Km2]

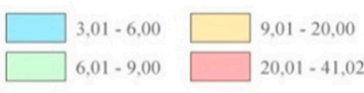

Saturated plots of land

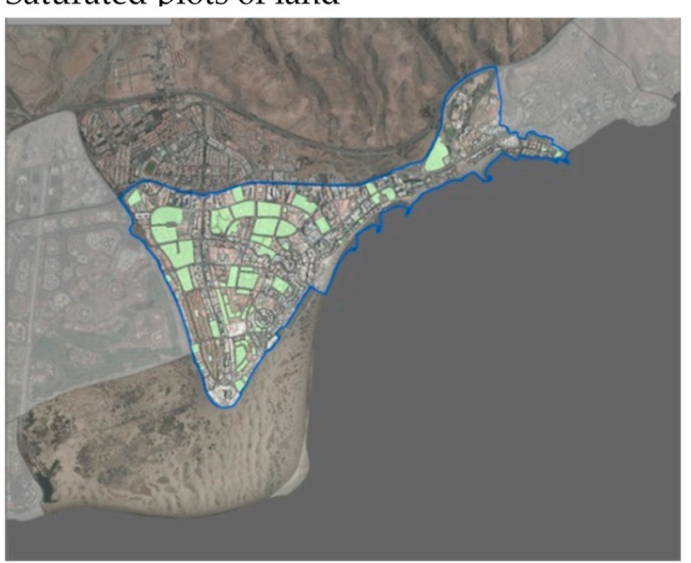

(b)

Figure 1. (a) Process of determining the accommodation density in Playa del Inglés (Gran Canaria). (b) Aaccommodation density in Playa del Inglés (Gran Canaria). 
Table 1. Condition indicators of accommodation saturation and their application in Playa del Inglés.

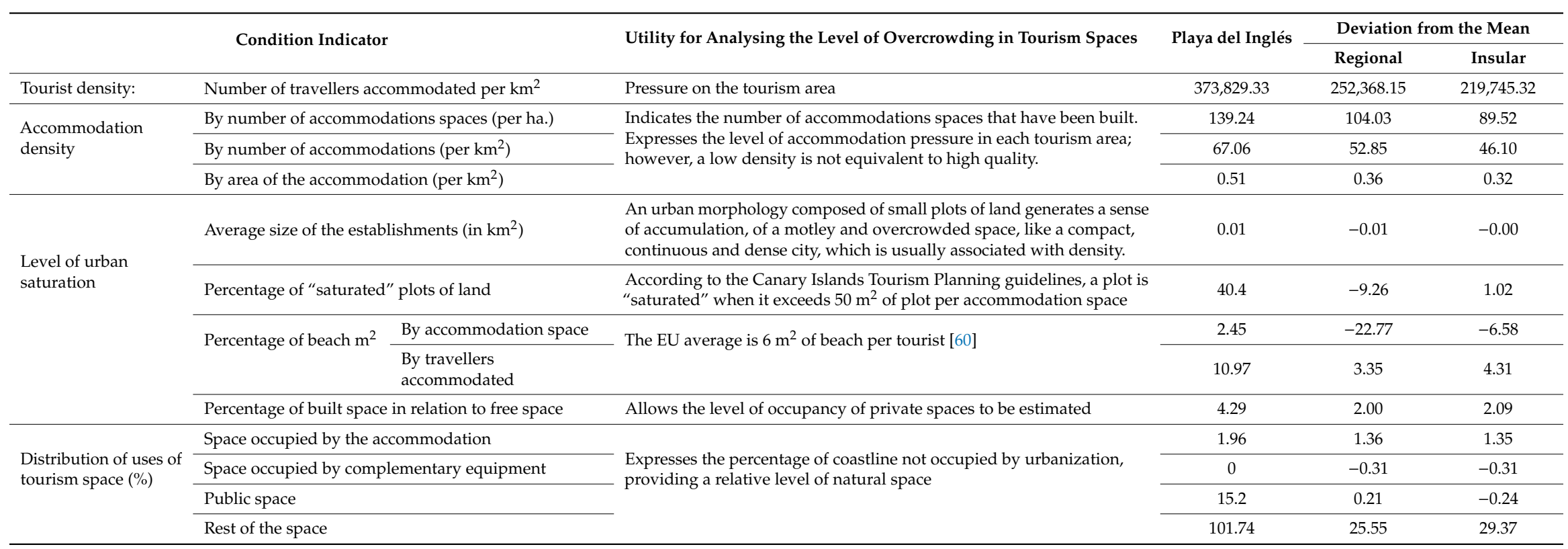

Source: ISTAC. Created by authors. 
The data on accommodation saturation in coastal tourism areas in the Canaries are largely the result of applying a specific regulation on accommodation density. Decree 7/1995, which approved Gran Canaria's Territorial Planning Law, and Law 7/1995, were the first to incorporate it into urban planning instruments for the Canary Islands. Both considered the density of each plot of land according to the concept of "net density", proposing specific thresholds. Thus, article 35 of Law 7/1995 established the maximum density permitted in the plots used for tourist accommodations, through a standard minimum of square meters of land per accommodations space, which could be no less than $60 \mathrm{~m}^{2}$. This decreased what had been set in Gran Canaria's Territorial Planning Law of $70 \mathrm{~m}^{2} /$ hotel accommodations space in Costa Norte, which implied that a maximum of 285 accommodations spaces could be authorized for a plot of 20,000 $\mathrm{m}^{2}$. In this way the relation between gross density (of the area) and net density (of the plot of land) became a basic control variable. This was an attempt to eliminate the excessive occupancy densities of the coastal tourism areas (30/50 $\mathrm{m}^{2}$ of plot per accommodations space), which had predominated to that point. It also attempted to establish low densities in still-undeveloped land by limiting the number of new accommodation spaces per buildable plot by fixing a net density (understood as a tourism ratio) directly applicable to new tourism authorizations, and introducing introduction various proportions of accommodations/services and equipment. This was converted into a variable to control the authorized gross density and in its consequent relation with net density.

Later, Decree 10/2001, 22 January, which regulated tourism standards and proposed higher densities, was inserted in the tourism moratorium mentioned above. These standards set the minimum sizes of the plots that could be occupied by new constructions of tourist accommodation establishments. It maintained the $60 \mathrm{~m}^{2}$ plot/accommodation space standard and added a $50 \mathrm{~m}^{2}$ standard for building renovation areas or zones, as well as a series of parameters related to infrastructures, equipment, buildability and heights; these parameters were slightly modified by article 13 of Decree 142/2010, 4 October, which approved the Tourist Accommodation Regulation. The territorial implementation of the minimum standard has generated a relation between accommodation capacity and the physical dimensions of new tourist accommodation establishments, giving rise to a construction model that Simancas [14] has denominated "horizontal hotels", in an attempt to imitate "Caribbean resorts".

Finally, the Canary Tourism Planning Guidelines, approved by Law 19/2003, consider a tourism area to be "saturated" when its gross density exceeds 200 accommodations spaces per hectare. This parameter is lower than the minimum required by Decree $42 / 2010$. The $42 \%$ of the tourism areas have "saturated" plots of land and, therefore, a significant number of tourist accommodation establishments whose plots do not surpass $50 \mathrm{~m}^{2}$ per accommodations space [58].

\section{Discussion: Critical Analysis of the Use of Accommodation Density as an Indicator of the Level of Urban Saturation of Tourism Areas of Canary Islands Destination}

The first weaknesses is that density is an arbitrary, ambiguous concept that is difficult, if not impossible, to define in absolute terms. There are also some doubts regarding its analytical relevance, despite the existence of scientific-academic literature with conceptual and methodological orientations that have some technical backing and acceptance among the scientific community that equate the level of tourist accommodation saturation to the negative perception of residents who experience the arrival of tourists during the irritation phase in Doxey's model [61], the stagnation stage of Butler's tourism life cycle [41] and Pizam's description of the social costs to destination communities [62]. This explains why little progress has been made in its application, as it is not easy to put in to operation through case studies [8], especially those related to sustainable tourism [63]. However, "the emphasis of the research has changed from general discussion to specific case studies and the main interest has been shifting from the search for numeric limits (fixed and standardized capacity thresholds for each type of tourism activity) to the development of theoretical-conceptual frameworks for planning and managing tourism areas that are configured as more flexible tools, within which a consensus is reached regarding tolerable levels of tourism impact" [64] (p. 221); in this sense, we highlight the methodologies that have incorporated the concept of capacity from a systematic and integral vision of tourism management, 
like those denominated Tourism Opportunity Spectrum [65], Social Carrying Capacity [6] and Limits of Acceptable Change or Visitor Impact Management [66].

One of the most relevant indicators proposed by Peeters et al. [16] to measure overtourism is tourism density (bed-nights $/ \mathrm{km}^{2}$ ). In addition to the relation with the density of the tourist accommodation, this supposes the second weakness: the level of accommodation saturation is defined by a set of evaluation standards (saturation benchmarks). Defert [67] proposed the "tourist function index", understood as the number of hotel and non-hotel accommodation spaces per every 100 inhabitants, pointing out that values greater than 1000 generated functional hypertrophy. UNWTO [3] considers 2 to 4 accommodations spaces per 100 inhabitants a generally acceptable ratio. Shelby and Heberlein [6] (p. 62) pose that "The carrying capacity has been exceeded when more than two thirds of the visitors feel overcrowded. If less than a third perceive overcrowding, the area probably is within its carrying capacity. When the perception of overcrowding is between those two thresholds, this rule provides no determination". Another approach is through the number of tourists and its relation with the surface area or with the local population $[68,69]$. In the same way, tourism density, expressed through indicators such as the number of accommodation spaces per 100 inhabitants or per $\mathrm{km}^{2}$, allows potential social or environmental pressures to be identified: while Machado considers that adequate thresholds for insular spaces are 20 accommodation spaces $/ \mathrm{km}^{2}$ and 0.5 accommodation spaces/inhabitant [70], the social-environmental tourism pressure index proposed by Fernández-Latorre and Díaz del Olmo [71] proposed 1000 accommodation spaces $/ \mathrm{km}^{2}$ as maximum values.

As can be observed, accommodation saturation is essentially an exercise in defining optimal limits or maximum and absolute numerical thresholds, in a way similar to identifying carrying capacities [72]. This explains why the process is excessively oriented toward the search for "magic numbers" through a mathematical formula or a mechanical method. Therefore, it is a strictly quantitative issue. This is an overly arbitrary simplification that denigrates this technique [73].

Similarly, there are no reference thresholds that allow the degree to which each variable fulfills accommodation saturation to be interpreted, while at the same time each tourist area presents a specific degree that cannot be extrapolated from one to the other. Furthermore, very few empirical studies have been published [74]. There is also no specific and generally accepted methodology to measure and evaluate these critical thresholds of accommodation density. Moreover, such maximum limits are generally difficult, if not impossible, to measure. They also involve value judgments, with the consequent degree of subjectivity. Its estimation cannot be solely based on scientific-technical criteria, despite the fact that certain reference values are regulated or are the result of objective technical measurements $[75,76]$, in that perhaps it does not correspond to the perception of tourism overcrowding. In the same way, an environmental bias can be observed [77].

Furthermore, these maximum accommodation density thresholds indicate the critical level at which saturation is perceived negatively. These are defined using a quantitative approach that employs various scientifically-valid condition indicators (Table 1) that are relevant, reliable, sensitive, predictive, comprehensible, comparable, quantifiable, cost-efficient, transparent and provide geographic coverage. This is why it is necessary to have a specific set of disaggregated statistical data at the micro-local scale. However, official public sources of information at the regional (autonomous community), insular and municipal levels do not provide them. This forces us to turn to different mechanisms, such as Geographic Information Systems (GIS), which are highly useful tools. These systems not only allow the spatial variables used to estimate accommodation overcrowding to be mapped-and, therefore, to create graphic representations-but also to generate and analyse geographic information, as well as systematize data with statistical value [78]. This makes it possible to establish a dynamic link between the data (attributes) and their spatial positioning, while simultaneously carrying out geometric analyses based on the topology of the elements. It also allows data to be obtained at an unprecedented scale, greater than that which is provided by official sources at any level of the administration. The data can also be presented at different levels of territorial aggregation, which resolves the major limitations to statistical information at the local level from a quantitative and qualitative perspective; thus, it is 
essential to define the usage distribution of the spaces in each tourism area, which is necessary to determine accommodation densities (per tourist accommodation establishment, per accommodation space, etc.). It also makes it possible to obtain statistical and descriptive information from the tourist area itself; thus, it contributes to more efficiently and effectively produce tourism statistics from geographic data. Indeed, the data generated by sources that are not purely statistical, such as those obtained from the GIS make it possible to improve the relevance, opportunity and timeliness of the products offered by official statistics regarding accommodation saturation.

The fourth weakness is related to the premise that urban-tourism spaces usually have "highly diversified densities and degrees of consumption and occupancy of the territory, depending on the model of the product offered in each setting and the scale at which consumption is established" [79] (p. 47). This means that coastal tourism areas behave like complex, heterogeneous and dynamic territorial systems, with formal and functional specificities according to its morphological characteristics. From this perspective, analysis of accommodation density should be done through the behaviour of those areas in territorial units that share a certain level of homogeneity, following the concept of "micro-destinations" [80].

The fifth weakness has to do with the implementation of accommodation density standards related to the frequent use of the "quality tourism" euphemism and the idea that larger establishments provide greater comfort to clients [13]. Both are based on the conceptual and outdated error of basing the quality of a tourist accommodation establishment on its rating and minimum physical parameters [79].

Similarly, the accommodation density is used in the Canaries Island destination as a basic reference to determine the quality of tourist accommodation establishments. Applying physical standards is among the strategies used to this end. This consists in using a legal approach to either establish a number of minimum physical parameters as quantifiable limits (and, for that matter, objectives), or desirable characteristics or levels of amenities, which vary according to the type of provision it is. Therefore, regarding regulated (that is, legally accredited) tourist accommodations, the most common is to set a minimum floor space for each bed place in $\mathrm{m}^{2}$, measured on the buildable lot. In addition to these parameters, there are other standards that affect urbanization, characterized by increased free space, etc., giving rise to urban areas that are determined by a certain way of developing a city. In this sense, the most frequent measures taken by destination management organizations and local governments to soften the negative effects of overtourism are related, among other actions, to improving the capacity of the infrastructures, accommodations and facilities. The above common measures are all in the realm of current tourism management strategies and practices, but are not necessarily the most appropriate. The lack of monitoring instruments or programs makes it difficult to assess the effectiveness of the measures in place.

However, it necessary to replace physical criteria to classify accommodation establishments. Quantitative criteria that exclusively consider the physical or functional parameters of a tourist establishment are no longer enough to obtain the quality of service that clients need and expect. At the same time, quality tourist accommodation establishments are not obtained just by reducing density, which is the significant standard; neither is low quality in tourist areas caused only by excessive density. According to the 2014 report published by the Confederación Española de Hoteles y Alojamientos Turísticos regarding the performance of hotels from 2008 to 2013, those that have specialized and distinguished themselves by offering quality service have positioned themselves in specific market niches, thereby increasing their rates and profits. Therefore, fixing tourism density standards in the Canaries has fallen into the common mistake of omitting the (subjective) perception of the client and, above all, meeting their expectations, which are measurable through qualitative and intangible criteria (service, personal attention, etc.).

As can be seen, it no longer makes sense to set physical parameters for quality that are measurable through categories; it is a continuation of an outmoded regulatory framework that is disconnected from the dynamic tourism market. This is due to the fact that there is no longer a direct relation between quality and size/stars. Moreover, such standards are no longer the sole and fundamental reference 
that clients use to choose tourist accommodation establishments for two fundamental reasons. On the one hand, their categories are estimated through characteristics such as the brand or the diversity of services or experiences (entertainment, sensations, emotions, etc.). On the other, access to information, in real time, through multiple channels supported by information and communication technologies and virtual platforms, reduces the importance of the tourist accommodation establishment's category; in this sense, online reputation - and, therefore, positive reviews given by the clients themselves on social networks-have become a decisive factor in choosing and recommending accommodations.

The sixth weakness is that accommodation overcrowding in coastal tourism areas is increasing due to the proliferation of buildings used in two situations associated with "residentialization": the residential tourism-vacation use of private tourist accommodations and the non-tourism residential use of homes. These processes have been consolidated as structural elements of the territorial and functional dynamic of coastal tourism areas in the Canaries; thus, $25.8 \%$ of the total population in 2015 was registered in municipalities that could be described as touristic, while $42.1 \%$ of the population of tourism municipalities resided in those areas [81].

The last weakness is associated with the relation between accommodation density as a parameter of urban saturation in a tourism area and the level of tourist satisfaction. In this sense, physical parameters that define accommodation density become more important when they are related to and treated as a measurement of tourist satisfaction and perception [36,38,82-85]. This provides a more perceptive (rather than qualitative) dimension to accommodation density, as it involves the tourist making value judgments regarding the predetermined thresholds. Tourist perceptions of the maximum limits of accommodation density are defined by subjective ideas, experiences and attitudes. This differentiates accommodation saturation from carrying capacity, which tends to only, or preferentially, consider the supply perspective [72]. However, the level of tourist accommodation saturation in coastal tourism destinations is not a decisive for tourist satisfaction. For example, according to statistics provided by the ISTAC, the repeat visitation rate was $77.3 \%, 16.9 \%$ had at least 10 prior visits and $64.9 \%$ had been too the Canaries before; this data shows that tourists are not uncomfortable in the Canaries, despite the high density of tourist accommodations. The level of accommodation density in Playa del Inglés is conditioned by the fact that, according to ISTAC, $80 \%$ of visitors rate their satisfaction as very good or good, which is above the regional (79.3\%) and insular (76.8\%) averages.

Similarly, overtourism is a more complex and multifaceted phenomenon than overcrowding. Further "crowding" and "overcrowding" should not be confused with density. Crowding generally refers to a psychological response to density, that is, to feelings of having a lack of privacy, or unwanted interactions [86-88] or places pressure on resources or has an impact on broader economic or social goals [89]. This is why considering satisfaction allows us to propose a weakness of using accommodation density, as well as how to avoid confusing it with crowding, consistent with the overtourism approach.

Finally, there are difficulties involved in measuring qualitative aspects of visitor satisfaction and, by extension, the deterioration of the quality of the tourist experience. In reality, when a tourist is "unsatisfied with a product" it is not just because accommodation oversaturation makes them uncomfortable, there are many different qualitative factors [90]. The intangible components not directly connected to the number of tourist accommodations that still affect tourist satisfaction include:

(a) The tourist profile, which is a mixture of socio-economic (income), cultural, demographic (age) and psychological characteristics [91,92], the different kinds of spaces and resources used, the type of activities they engage in [93], their personal motivations (preferences, behaviour and assessments), their psychological adaptation to different conditions and types of activities $[90,94]$, familiarity with the destination [82], etc.

(b) The behaviour of the local population. If the tourist perceives the residents to be friendly, they are more likely to forgive some of the negative effects of the feeling of overcrowding.

(c) The obsolescence of tourist accommodation establishments (physical, functional, business model, organizational model, forms of segmentation, sales channels, etc.). This is not necessarily caused 
by poor management, but rather because they have insufficient utility or functionality or because tastes, motivations and demands change.

(d) Using as a reference Wohlwill's level of adaptation theory (1966), tourists from high-density urban areas prefer concentrated areas that are different from their normal environment, to provide contrast, but not too different [38]. Further, the tourists generally are more tolerant of visitor density when visiting a culture other than their own $[10,11]$. Therefore, coastal tourist areas can capture clients who are accustomed to living in heavily concentrated environments.

Repeat visits, if associated with a high level of satisfaction, is a positive indicator of tourist loyalty [95], ensuring the probability that they will return to the destination. However, while visitors are more tolerant of overcrowding on initial visits to a destination, if they see changes when they return will they stop going, in accordance with the "last settler syndrome" [80].

It has been highlighted that crowding can also be positive [63]. This vision has been largely overlooked [96], despite its growing relevance in tourism [97]. Notions of 'being in the right place' in the wider context of 'following' trends have gained importance because of information cascades and the concentration of news flows in the age of social media [98], as well as an increasing focus by consumers on the acquisition of unique experiences, rather than material possessions as markers of identity [99] in social media channels.

Once again there is a lack of data regarding the level of satisfaction at the micro-local level. Therefore, it is necessary to use other response indicators (Table 2). These describe tourist perception of accommodation saturation in coastal tourism areas. Although they depend on certain socio-economic conditions, these response indicators detect individual and collective reactions to the accommodation capacity of each tourist destination/area, defined by condition indicators: while the latter allow the current situation of Canarian tourist areas to be defined, response indictors provide the evidence needed to check if tourist perceive a level of accommodation saturation, while resolving the lack of necessary surveys. This information is evaluated by comparing it with regional and insular averages (Table 2) and by its positive temporal dynamic (Table 3).

Table 2. Response indicators of accommodation overcrowding and their application in Play del Inglés.

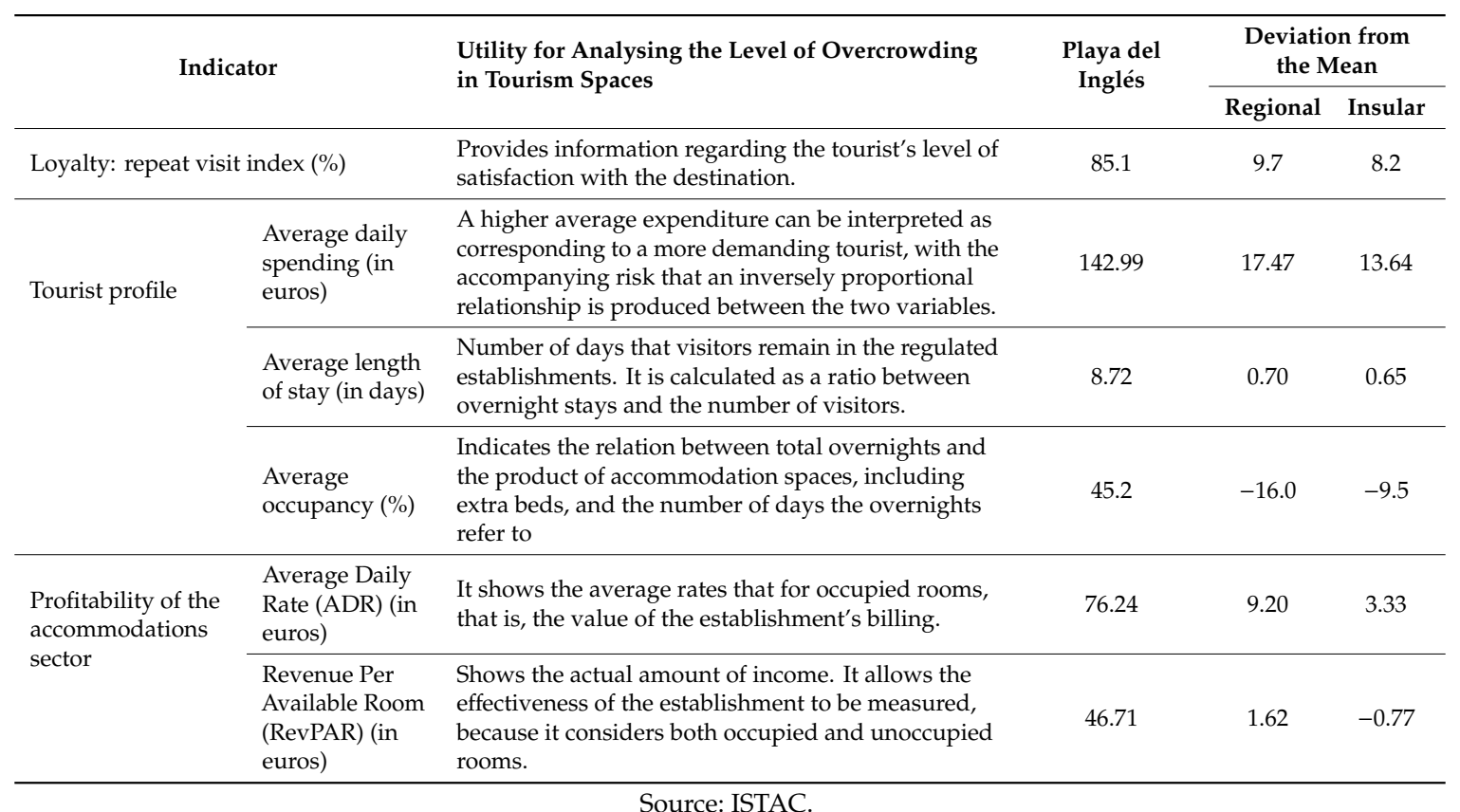


Table 3. Evolution of response indicators of accommodation overcrowding in Playa del Inglés.

\begin{tabular}{ccccccc}
\hline & Visitors & $\begin{array}{c}\text { Overnight } \\
\text { Stays }\end{array}$ & $\begin{array}{c}\text { Average } \\
\text { Length of } \\
\text { Stay }\end{array}$ & $\begin{array}{c}\text { Occupancy Index per } \\
\text { Rooms-Apartments }\end{array}$ & $\begin{array}{c}\text { Occupancy Index per } \\
\text { Accommodation } \\
\text { Space }\end{array}$ & $\begin{array}{c}\text { Average Daily Rate } \\
\text { (ADR) (in Euros) }\end{array}$ \\
\hline $\mathbf{2 0 0 9}$ & $1,472,345$ & $13,093,999$ & 8.89 & 66.71 & 53.71 & 51.03 \\
\hline $\mathbf{2 0 1 0}$ & $1,390,884$ & $12,316,260$ & 8.85 & 66.48 & 51.40 & 53.11 \\
\hline $\mathbf{2 0 1 1}$ & $1,453,881$ & $12,958,630$ & 8.91 & 72.07 & 55.44 & 56.51 \\
\hline $\mathbf{2 0 1 2}$ & $1,379,927$ & $12,219,271$ & 8.86 & 67.66 & 52.15 & 59.44 \\
\hline $\mathbf{2 0 1 3}$ & $1,394,002$ & $12,184,316$ & 8.74 & 70.10 & 53.07 & 62.20 \\
\hline $\mathbf{2 0 1 4}$ & $1,384,916$ & $12,028,550$ & 8.69 & 69.67 & 52.68 & 66.54 \\
\hline $\mathbf{2 0 1 5}$ & $1,449,250$ & $12,471,578$ & 8.61 & 69.77 & 56.44 & 69.92 \\
\hline $\mathbf{2 0 1 6}$ & $1,616,666$ & $13,944,100$ & 8.63 & 80.12 & 64.34 & 75.24 \\
\hline $\mathbf{2 0 1 7}$ & $1,676,729$ & $14,183,346$ & 8.46 & 79.67 & 65.02 & 76.24 \\
\hline
\end{tabular}

\section{Conclusions}

Describing a tourism destination as "saturated" from the perspective of overtourism, implies the sensation that there are excessive amounts of accommodations places (accommodation density). It verifies the existence of a negative impact, understood as a change regarded as undesirable by the tourists.

In order to determine the level of accommodation saturation in a coastal tourism area; the situation must first be simplified by identifying and examining the most relevant aspects, in order to offer synthetic, measurable information regarding how tourists perceive the tourism accommodation capacity. It can be used to estimate the limits (capacity) of the area to attract tourists before they perceive the negative impacts, when the specific maximum threshold for satisfaction is exceeded. The usefulness of this parameter is based on its capacity to define "the level of tourist use that provides sustained quality recreation" [62,100]. However, to determine the optimal accommodation density of a coastal tourism area, we must consider more than just pressure and condition indicators to define accommodation capacity in each tourist destination/area; we also have to examine response indicators related to the behaviour of the demand and, more specifically, the opinion of the tourists through their level of satisfaction.

Furthermore, estimating the optimal limit for accommodation saturation is not an end in and of itself, but rather an instrument that can provide continuous, relevant information to those in charge of making decisions related to planning and managing mature tourist destinations. Therefore, it is a management concept which reflects the objectives of managers or those responsible for satisfying tourists and local residents [101].

The same occurs with the need to correct excessive use or to adjust the demand to the supply of tourist accommodations. In this sense, accommodation density can be employed as a reference to properly manage the growth of tourism. In addition, the perception of accommodation saturation by tourists can set off alarms when tourist satisfaction with the destination drops off sharply. Therefore, it is a mechanism that can efficiently determine the permissibility or prohibition of new tourist accommodation uses and, therefore, to properly define the types, behaviours, rhythms and intensity of development, the rules and regulations regarding the availability and distribution of terrain, in accordance with the functionality and capacities of the provisions, infrastructures and essential public services (electricity supply, water storage, road systems, waste treatment and other general systems).

The effects of accommodation saturation in a coastal tourism area are, only recently, being discussed in relation with solving social conflicts; however its link with environmental impacts has long been known. Saturation and crowding are the most obvious manifestations. These situations are traditionally addressed in carrying capacity studies without achieving the objectives that are sought 
after. However, while it continues to be a popular concept to assess the negative consequences of tourism, the usefulness has been questioned of the overtourism perspective.

Just as occurs with tourist carrying capacity, analyzing the level of accommodation overcrowding in a coastal tourism area plays a heavy role in maintaining and improving competitiveness. In this sense, tourist satisfaction achieved when the tourist area is not seen as saturated is a decisive factor not only to create an attractive image, but also to encourage repeat visits (loyalty), because it has a positive effect on post-sale behaviour and, hence, recommendations and online reputation, both of which are essential to attract new tourists. Moreover, the fact that a tourist area does not show signs of accommodation saturation can be used in promotional campaigns to capture new clients.

In this context, tourist satisfaction is a perception factor that can be used to estimate when a coastal tourism area may be considered saturated by tourist accommodations upon reaching a minimum level. More specifically, the accommodation density is a parameter for urban saturation in a tourism area, when related to the level of tourist satisfaction. However, we have verified in this paper that there is no correlation between these two variables, at least in coastal tourism areas in the Canaries, as high-density areas produce high levels of tourist satisfaction. Therefore, we propose that the level of tourist accommodation saturation in coastal tourism destinations is not an indicator for tourist satisfaction. Moreover, the impacts of crowding on appraisals and behaviour are complex. Substantial research conducted in related contexts has shown that crowding can reduce people's satisfaction, attitude, and loyalty. The crowding assessments may vary considerably across visitor types, contexts, times, and territories [54]. The crowding studies should be conducted also in settings in which tourists have a range of norms and tolerances, and overall negativity to visitor density should not be taken for granted [96,101].

Definitely, tourist accommodation density is a measure the level of saturation in urban coastal tourism areas. We believe this is necessary because it is an indicator used to determine a state that is undesirable for tourists, when certain carrying capacities of the tourist-urban area are considered to have too many tourist accommodations and bed places. Thus, a coastal tourism area can be considered saturated by accommodations when tourist satisfaction falls to a minimum level, causing interest and tolerance level in the destination to be unacceptably altered. This concept is also inherent to the notion of sustainability. In this way saturation and carrying capacity have a strict relation with the overtourism. This idea relates tourist accommodation density with the possible feeling of crowding and, at the same time, with overtourism [1].

Finally, we must remember that "growth is not the enemy, but rather how we manage it" [1]. This approach applied to the excessive density of accommodations implies the need for specific regulation and, above all, sustainable management and to consider quantitative as well as qualitative indicators to ensure a comprehensive vision of tourism's impact on the destination. Similarly, the result of tourist accommodation density measurements will always depend on the territorial context. Thus a tailor-made management strategy must be developed to cope with the current situation in each specific destination [1]. Similarly, the consideration of a tourist accommodation saturated will vary with the values of those asking the questions and establishing the conditions for measurement.

Author Contributions: These authors have contributed equally in the research design and development, the data analysis and the writing of the paper.

Funding: This article is based research carried out in the projects "Analysis of urban stability as a strategy to regenerate public space in coastal tourism areas", financed by the CajaCanarias Foundation, and "Tourist saturation in Spanish coastal destinations tourist. Decrease strategies tourist", financed by the Ministry of Science, Innovation and Universities.

Conflicts of Interest: The authors declare no conflict of interest.

\section{References}

1. World Tourism Organization. 'Overtourism'?-Understanding and Managing Urban Tourism Growth beyond Perceptions; UNWTO: Madrid, Spain, 2018. 
2. World Tourism Organization. Indicadores de Sostenibilidad para los Destinos Turísticos. Guía Práctica; UNWTO: Madrid, Spain, 2005.

3. World Tourism Organization. Risks of Saturation of Tourist Carrying Capacity Overload in Holiday Destinations; UNWTO: Madrid, Spain, 1983.

4. Mathieson, A.; Geoffrey, W. Tourism: Economic, Physical and Social Impacts; Longman: London, UK, 1982.

5. Kotler, P.; Bowen, J.T.; Makens, J. Marketing for Hospitality and Tourism; Pearson: Upper Saddle River, NJ, USA, 2005.

6. Shelby, B.; Heberlein, T. Social carrying capacity in recreation settings: Evolution, appraisal and application. Leis. Sci. 1984, 6, 453-473.

7. O'Reilly, A. Tourism carrying capacity: Concepts and issues. Tour. Manag. 1986, 7, 254-258. [CrossRef]

8. Echamendi, P. La capacidad de carga turística. Aspectos conceptuales y normas de aplicación. An. Geogr. Univ. Complut. 2001, 21, 11-30.

9. López-Bonilla, J.M.; López-Bonilla, L.M. La capacidad de carga psicológica del turista como indicador del turismo sostenible. Boletín Económico ICE 2007, 2911, 25-35.

10. Li, L.; Zhang, J.; Nian, S.; Zhang, H. Tourists' perceptions of crowding, attractiveness, and satisfaction: A second-order structural model. Asia Pac. J. Tour. Res. 2017, 22, 1250-1260. [CrossRef]

11. Jin, Q.; Hu, H.; Kavan, P. Factors Influencing Perceived Crowding of Tourists and Sustainable Tourism Destination Management. Sustainability 2016, 8, 976. [CrossRef]

12. Zehrer, A.; Raich, F. The impact of perceived crowding on customer satisfaction. J. Hosp. Tour. Manag. 2016, 29, 88-98. [CrossRef]

13. Alegre, J.; Garau, J. Tourist satisfaction and dissatisfaction. Ann. Tour. Res. 2010, 37, 52-73. [CrossRef]

14. Simancas, M. La moratoria turística de Canarias. In La Reconversión de un Destino Turístico Maduro Desde la Ordenación del Territorio; Servicio de Publicaciones de la Universidad de La Laguna: San Cristóbal de La Laguna, Spain, 2015.

15. Simancas, M.; García, J.I.; Greifemberg, C.; Peñarrubia, P. Strategies to improve the quality and competitiveness of coastal tourism areas: Applying tourism standards. J. Tour. Anal. 2018, 25, 68-90. [CrossRef]

16. Peeters, P.M.; Gössling, S.; Klijs, J.; Milano, C.; Novelli, M.; Dijkmans, C.H.; Eijgelaar, E.; Hartman, S.; Heslinga, J.; Isaac, R.; et al. Research for TRAN Committee-Overtourism: Impact and Possible Policy Responses, European Parliament; Policy Department for Structural and Cohesion Policies: Brussels, Belgium, 2018.

17. Huete, R.; Mantecón, A. El auge de la turismofobia, ¿hipótesis de investigación o ruido ideológico? PASOS Rev. Tur. Patrim. Cult. 2018, 16, 9-19. [CrossRef]

18. Routledge, P. Selling the rain', resisting the sale: Resistant identities and the conflict over tourism in Goa. Soc. Cult. Geogr. 2001, 2, 221-240. [CrossRef]

19. Koens, K.; Postma, A.; Papp, B. Is Overtourism Overused? Understanding the Impact of Tourism in a City Context. Sustainability 2018, 10, 4384. [CrossRef]

20. Martin, B.; Uysal, M. An examination of the relationship between carrying capacity and the tourism lifecycle: Management and policy implications. J. Environ. Manag. 1990, 31, 27-333. [CrossRef]

21. Vera, F.; Ivars, J. Medición de la sostenibilidad en un destino turístico masivo: Presiones, percepciones y respuestas políticas en Torrevieja, España. J. Sustain. Tour. 2003, 11, 181-203.

22. Perkumiené, D.; Pranskuuniené, R. Overtourism: Between the Right to Travel and Residents' Rights. Sustainability 2019, 11, 21-38. [CrossRef]

23. McKinsey \& Company. Coping with Success: Managing Overcrowding in Tourism Destinations; World Travel \& Tourism Council: London, UK, 2017.

24. Alvarez-Sousa, A. The Problems of Tourist Sustainability in Cultural Cities: Socio-Political Perceptions and Interests Management. Sustainability 2018, 10, 503. [CrossRef]

25. Milano, C. Turismofobia: Cuando el turismo entra en la agenda de los movimientos sociales. Marea Urbana 2017, 1, 5-8.

26. Milano, C. Overtourism, social unrest and tourismphobia. A controversial debate. PASOS Rev. Tur. Patrim. Cult. 2018, 16, 551-564. [CrossRef]

27. Peeters, P. Why space tourism will not be part of sustainable tourism. Tour. Recreat. Res. 2018, 43, 540-543. [CrossRef]

28. Benner, M. From Overtourism to Sustainability: A Research Agenda for Qualitative Tourism Development in the Adriatic; MPRA Paper No. 92213; Munich Personal RePEc Archive (MPRA): Munich, Germany, 2019. 
29. Jacobsena, J.; Iversenb, N.; Hemc, L. Hotspot crowding and over-tourism: Antecedents of destination attractiveness. Ann. Tour. Res. 2019, 76, 53-66. [CrossRef]

30. Oklevik, O.; Gössling, S.; Michael, H.; Jens, K.; Petter, G.; McCabe, S. Overtourism, optimisation, and destination performance indicators: A case study of activities in Fjord Norway. J. Sustain. Tour. 2019, 1-21. [CrossRef]

31. Seraphin, H.; Korstanje, M.; Gowreesunkar, V. Diaspora and ambidextrous management of tourism in post-colonial, post-conflict and post-disaster destinations. J. Tour. Cult. Chang. 2019, 1-20. [CrossRef]

32. Seraphin, H.; Sheeran, P.; Pilato, M. Over-tourism and the fall of Venice as a destination. J. Destin. Mark. Manag. 2018, 9, 374-376. [CrossRef]

33. Mihalache, M.; Mihalache, O. Organisational ambidexterity and sustained performance in the tourism industry. Ann. Tour. Res. 2016, 56, 128-163. [CrossRef]

34. Muler, V.; Coromina, L.; Galí, N. Overtourism: residents' perceptions of tourism impact as an indicator of resident social carrying capacity-Case study of a Spanish heritage town. Tour. Rev. 2018, 73, 277-296. [CrossRef]

35. Butler, R. The concept of carrying capacity for tourism destinations: Dead or merely buried? In Tourism Development: Environmental and Community Issues; John Wiley \& Sons: Chichester, UK, 1997.

36. Saveriades, A. Establishing the social tourism carrying capacity for the tourist resorts of the east coast of the Republic of Cyprus. Tour. Manag. 2000, 21, 147-156. [CrossRef]

37. Price Waterhouse. Capacidad Potencial de Absorción de Turismo del Litoral Español; Secretaría General de Turismo: Madrid, Spain, 1990.

38. Navarro, E. Aplicaciones Metodológicas Sobre la Evaluación de la Capacidad de Carga en la Costa del Sol Occidental: Infraestructura Básica y Percepción de la Demanda. Ph.D. Thesis, University of Málaga, Málaga, Spain, 2000.

39. Coccossis, H.; Mexa, A.; Collovini, A.; Parpairis, A.; Konstandoglou, M. Defining, Measuring and Evaluating Carrying Capacity in European Tourism Destinations; European Union: Athens, Greece, 2001.

40. Coccossis, H.; Mexa, A. Tourism carrying capacity: Methodological considerations. In The Challenge of Tourism Carrying Capacity: Theory and Practice; Ashgate: London, UK, 2004.

41. Butler, R. The concept of a tourism area cycle of evolution: Implications for the management of resources. Can. Geogr. 1980, 24, 5-12. [CrossRef]

42. Chadefaud, M. Aux Origines du Tourisme Dans Les Pays de l'Adour; Département de Géographie et d'Aménagement de l’Université de Pau: Pau, France, 1987.

43. Agarwal, S. The resort cycle and seaside tourism: An assessment of its applicability and validity. Tour. Manag. 1997, 18, 65-73. [CrossRef]

44. Torres, E.; Navarro, E. La congestión urbanística como factor reductor de la calidad turística y de vida en los destinos maduros. Estud. Turísticos 2007, 172-173, 193-199.

45. Harrison, D. Pro-poor Tourism: A critique. Third World Q. 2008, 29, 851-868. [CrossRef]

46. Scheyvens, R. Pro-Poor Tourism: Is there value beyond the rhetoric? Tour. Recreat. Res. 2009, 34, $191-196$. [CrossRef]

47. Milano, C. Overtourism y Turismofobia: Tendencias Globales y Contextos Locales; The Ostelea School of Tourism \& Hospitality: Barcelona, Spain, 2017.

48. Postma, A.; Schmuecker, D. Understanding and overcoming negative impacts of tourism in city destinations: Conceptual model and strategic framework. J. Tour. Futures 2017, 3, 144-156. [CrossRef]

49. Martín, J.; Guaita, J.; Salinas, J. An Analysis of the Factors behind the Citizen's Attitude of Rejection towards Tourism in a Context of Overtourism and Economic Dependence on This Activity. Sustainability 2018, 10, 2851. [CrossRef]

50. Luque, A.; Gómez, M.; Pelaez, M. Starting to enjoy nature in Mediterranean mountains: Crowding perception and satisfaction. Tour. Manag. 2018, 25, 83-103.

51. Bellini, N.; Go, F.M.; Pasquinelli, C. Urban Tourism and City Development: Notes for an Integrated Policy Agenda. In Tourism in the City; Springer International Publishing: Cham, Switzerland, 2016; pp. 333-339.

52. Novy, J.; Colomb, C. Urban tourism and its discontents: An introduction. In Protest and Resistance in the Tourist City; Routledge: London, UK, 2016; pp. 15-44. 
53. Koens, K.; Postma, A. Understanding and managing visitor pressure in urban tourism. A Study to into the Nature of and Methods Used to Manage Visitor Pressure in Six Major European Cities, Unpublished Technical Report; Breda, Leeuwarden, Holland, 2017.

54. Navarro, E.; Damian, I.M.; Fernández, A. Carrying capacity model applied in coastal destinations. Ann. Tour. Res. 2013, 43, 1-19. [CrossRef]

55. Oreja, J.; Parra, E.; Yanes, V. The sustainability of island destinations: Tourism area life cycle and teleological perspectives: The case of Tenerife. Tour. Manag. 2007, 29, 53-65. [CrossRef]

56. Simancas Cruz, M. La ordenación territorial del turismo en espacios insulares. Ciudad y Territorio. Estud. Territ. 2015, 185, 445-462.

57. Exceltur. MoniTUR 2009. Monitor de Competitividad Turística Relativa de las Comunidades Autónomas Españolas; Exceltur: Madrid, Spain, 2010.

58. Simancas, M. Determinación del Grado del Masificación del Destino Turístico Islas Canarias; Promotur Turismo de Canarias/Fundación General Universidad de La Laguna: San Cristóbal de La Laguna, Spain, 2014.

59. García, J. El Impacto Territorial del Tercer Boom Turístico de Canarias. Ph.D. Thesis, University of La Laguna, San Cristóbal de La Laguna, Spain, 2014.

60. Gallego, I.; Moniche, A. Sistema de indicadores territoriales para un destino turístico. In Conferencia Mundial: La Cuenta Satélite de Turismo (CST): Comprender el Turismo y Diseñar Estrategias; UNWTO: Madrid, Spain, 2005.

61. Doxey, G.V. A causation theory of visitor/resident irritants: Methodology and research inferences. In Proceedings of the Travel Research Association 6th Annual Conference; Travel Research Association: San Diego, CA, USA, 1975; pp. 195-198.

62. Pizam, A. Tourism's impacts: The social costs to the destination community as perceived by its residents. J. Travel Res. 1978, 16, 8-12. [CrossRef]

63. Choi, H.C.; Sirakaya, E. Sustainability indicators for managing community tourism. Tour. Manag. 2006, 27, 1274-1289. [CrossRef]

64. Hernández, M.G.; de la Calle Vaquero, M.; García, M.D. Capacidad de carga turística y espacios patrimoniales. Aproximación a la estimación de la capacidad de carga del conjunto arqueológico de Carmona (Sevilla, España). Boletín Asoc. Geógrafos Españoles 2011, 57, 219-241.

65. Butler, R.; Waldbrook, L. A new planning tool: The tourism opportunity spectrum. J. Tour. Stud. 2003, 14, 21-32.

66. Stankey, G.; Cole, D.; Lucas, R.; Petersen, M.; Frissell, S. The Limits of Acceptable Change (LAC) System for Wilderness Planning; Intermountain Forest and Range Experiment Station: Ogden, UT, USA, 1985.

67. Defert, P. Le Taux de Fonction Touristique: Mise au Point et Critique. In Les Cahiers du Tourisme; Serie C-5; Université d'Aix-Marseille: Aix-en-Provence, France, 1967.

68. McElroy, J.L.; De Alburquerque, K.; Dioguardi, A. Applying the Tourist Destination Life-Cycle Modell to small Caribbean and Pacific Islands. World Travel Tour. Rev. 1993, 3, 236-244.

69. Thomas, R.N.; Pigozzi, B.W.; Sambrook, R.A. Tourist Carrying Capacity Measures: Crowding Syndrome in the Caribbean. Prof. Geogr. 2005, 57, 13-20.

70. Machado, A. Ecología, Medio Ambiente y Desarrollo Turístico en Canarias; Gobierno de Canarias: Santa Cruz de Tenerife, Spain, 1990.

71. Fernández Latorre, F.M.; del Olmo, F.D. Huella ecológica y presión turística socio-ambiental. Aplicación en Canarias. Boletín Asoc. Geógrafos Españoles 2011, 57, 147-174.

72. McCool, S.; Lime, D. Tourism carrying capacity: Tempting fantasy or useful reality? J. Sustain. Tour. 2001, 9, 372-388. [CrossRef]

73. Vera, F.; Baños, C. Turismo, territorio y medio ambiente. Pap. Econ. Española 2004, 102, 271-286.

74. López, J.; López, L. La capacidad de carga turística: Revisión crítica de un instrumento de medida de sostenibilidad. El Periplo Susten Table 2008, 15, 123-150. [CrossRef]

75. Vera, J. Planificación y Gestión del Desarrollo Turístico Sostenible: Propuestas Para la Creación de un Sistema de Indicadores; Instituto Universitario de Geografía: Alicante, Spain, 2001.

76. Vera, F.; Ivars, J. Measuring sustainability in a mass tourist destination: Pressures, perceptions and policy responses in Torrevieja, España. J. Sustain. Tour. 2003, 11, 181-203.

77. López, F.; Torres, A.; Font, X.; Serrano, D. Gestión sostenible de destinos turísticos: La implementación de un sistema de indicadores de turismo en los destinos de la provincia de Barcelona. Boletín Asoc. Geógrafos Españoles 2018, 77, 428-461. [CrossRef] 
78. Simancas, M.; Peñarrubia, P.; Suárez, D.; Temes, R. El uso de sistemas de información geográfica en la determinación del grado de masificación alojativa de las áreas turísticas consolidadas de litoral. In Tecnologías de la Información Geográfica Perspectivas Multidisciplinares en la Sociedad del Conocimiento. XVIII Congreso Nacional de Tecnologías de la Información Geográfica; Asociación de Geógrafos Españoles/Departament de Geografia de la Universitat de València: Valencia, Spain, 2018; pp. 455-466.

79. Barrado, D. El concepto de destino turístico. Una aproximación geográfico-territorial. Estud. Turísticos 2004, $160,45-68$.

80. Hernández, R.; Simancas, M.; González, A.; Rodríguez, J.; García, J.; González, Y. Identifying micro-destinations and providing statistical information. A pilot study in the Canary Islands. Curr. Issues Tour. 2016, 19, 771-790. [CrossRef]

81. Simancas, M.; Peñarrubia, P.; Temes, R.; Horcajada, T. La transformación de destinos turísticos en ciudades: Análisis geodemográfico de las áreas turísticas de litoral de Canarias (España). Rev. Estud. Reg. 2018, 112, 125-152.

82. Getz, D. Capacity to absorb tourism. Concepts and implications for strategic planning. Ann. Tour. Res. 1983, 10, 239-263. [CrossRef]

83. Sowman, M. A procedure for assessing recreational carrying capacity of coastal resort areas. Landsc. Urban Plan. 1987, 14, 331-344. [CrossRef]

84. Roig, F. Análisis de la relación entre capacidad de carga física y capacidad de carga perceptual en playas naturales de la isla de Menorca. Investig. Geográficas 2003, 31, 107-118. [CrossRef]

85. Alipour, H.; Altinay, M.; Hussain, K.; Sheikhani, N. Perceptions of the beach users: A case study of the coastal areas of North Cyprus towards establishment of a carrying capacity. FIU Rev. 2007, 24, 28-48. [CrossRef]

86. Crothers, C.; Kearns, R.A.; Lindsey, D. Housing in Manukau City: Overcrowding, Poor Housing and Their Consequences; Department of Sociology, University of Auckland: Auckland, New Zealand, 1993.

87. Gove, W.R.; Hughes, M. The Effects of Crowding Found in The Toronto Study: Some Methodological and Empirical Questions. Am. Sociol. Rev. 1980, 45, 864-870. [CrossRef]

88. Gray, A. Definitions of Crowding and the Effects of Crowding on Health: A Literature Review; Ministry of Social Policy Te Manatu- $\mathrm{mo}^{-}$nga $^{-}$Kaupapa Oranga Tangata: Wellington, New Zealand, 2001.

89. Johnston, R.J.; Gregory, D.; Pratt, G.; Watts, M. The Dictionary of Human Geography; Blackwell Publishers: Oxford, UK, 2005.

90. Navarro, E. Indicadores para la evaluación de la capacidad de carga turística. Ann. Tour. Res. 2005, 7, 397-422.

91. Santana, Y.; Hernandez, J. Estimating the effect of overcrowding on tourist attraction: The case of Canary Islands. Tour. Manag. 2011, 32, 415-425. [CrossRef]

92. Rasoolimanesh, S.; Jaafar, M.; Marzuki, A.; Abdullah, S. Tourist's perceptions of crowding at recreational sites: The case of the Perhentian Islands. Anatolia Int. J. Tour. Hosp. Res. 2016, 28, 41-51. [CrossRef]

93. Mieczkowski, Z. Environmental Issues of Tourism and Recreation; University Press of American: Boston, MA, USA, 1995.

94. Klanjšček, J.; Geček, S.; Marn, N.; Legović, T.; Klanjšček, T. Predicting perceived level of disturbance of visitors due to crowding in protected areas. PLoS ONE 2018, 13, e0197932. [CrossRef]

95. Aguiló, E.; Alegre, J.; Sard, M. The persistence of the sun and sand tourism model. Tour. Manag. 2005, 26, 219-231. [CrossRef]

96. Neuts, B.; Nijkamp, P. Tourist crowding perception and acceptability in cities: An applied modelling study on Bruges. Ann. Tour. Res. 2012, 39, 2133-2153. [CrossRef]

97. Popp, M. Positive and negative urban tourist crowding. Florence, Italy. Tour. Geogr. 2012, 14, 50-72. [CrossRef]

98. Turkle, S. Reclaiming Conversation; Basic Books: New York, NY, USA, 2015.

99. Addis, M.; Holbrook, M. On the conceptual link between mass customisation and experiential consumption: An explosion of subjectivity. J. Consum. Behav. Int. Res. Rev. 2001, 1, 50-66. [CrossRef]

100. Lindberg, K.; Mccool, S.; Stankey, G. Rethinking carrying capacity. Ann. Tour. Res. 1997, 24, 461-465. [CrossRef]

101. Neuts, B.; Nijkamp, P.; Leeuwen, E. Crowding externalities from tourist use of urban space. Tour. Econ. 2012, 18, 649-670. [CrossRef]

(C) 2019 by the authors. Licensee MDPI, Basel, Switzerland. This article is an open access article distributed under the terms and conditions of the Creative Commons Attribution (CC BY) license (http://creativecommons.org/licenses/by/4.0/). 